\title{
Technical Efficiency of Cabbage Farming (Brassica oleracea) With Stochastic Frontier Analysis (SFA) Approach in Purwodadi - Pasuruan
}

\author{
Suaibatul Miskiyah $^{1 *}$, Syafrial $^{2}$, Sujarwo ${ }^{2}$ \\ ${ }^{1}$ Postgraduate, Faculty of Agriculture, Brawijaya University, Jl. Veteran, Malang 65145, Indonesia \\ ${ }^{2}$ Social Economics Department, Faculty of Agriculture, Brawijaya University, Jl. Veteran, Malang 65145, \\ Indonesia
}

Received: 27 April 2020; Revised: 13 May 2020; Accepted: 22 February 2021

\begin{abstract}
This study was aimed to analyze the factors affecting the cabbage production, the level of technical efficiency of cabbage farming, the factors affecting technical inefficiency, and the profits of cabbage farming. The location was determined purposively on the basis that it is the center of vegetable cultivation. The respondents were 67 farmers chosen using the Yamane formula sampling technique. This research used frontier software 4.1 data analysis method with Maximum Likelihood Estimation (MLE) approach and Tobit regression. The results showed that land, labor, seeds, organic fertilizers, urea fertilizers, za fertilizers and npk fertilizers were real influential factors. Meanwhile, pesticides were insignificantly influenced. The mean technical efficiency in the research site was 0.903 for the distribution of technical efficiency, so that the cabbage production was rated as high efficiency. Age, education and credit access dummy contributed a major impact on technological inefficiency. The income from cabbage farming per planting season per hectare was Rp35,524,300 from cash costs and Rp31,051,800 from total costs.
\end{abstract}

Keywords: cabbage; technical efficiency; stochastic frontiers

\section{How to cite:}

Miskiyah, S. (2021). Technical Efficiency of Cabbage Farming ( Brassica oleracea ) With Stochastic Frontier Analysis ( SFA ) Approach in Purwodadi - Pasuruan. 32(1), 26-36. https://doi.org/10.21776/ub.habitat.2021.032.1.4

\section{Introduction}

Cabbage (Brassica oleracea) is a subtropical vegetable plant which has a great opportunity to be cultivated in Indonesia. Cabbage has a strong potential to grow. In addition to meeting domestic needs, cabbage also has the possibility to be an export product. In practice, however, farmers still face some problems or obstacles in the cultivation technique of cabbage, such as the use of seeds, fertilizers and pesticides that are not accurate in terms of both dose and time. This obstacle can reduce the cabbage production, particularly during rainy season. Farmers have to spend a lot of money during this season for the care and pests and diseases control. Cabbage farmers complained of low yields, for instance the average yields or real production ranging from 24 to 28 tons/hectare. Whereas the seeds used are the

${ }^{*}$ Corressponding author.

E-mail: suaibatulmiskiyah@gmail.com

Telp: +62857-9192-9721
Grand 11 variety in which the potential production level can reach 40-50 tonnes/hectare (Firman, 2019).

The potential level of production is closely linked to the effective use of input or production factors, the less accurate the number and combination of these production factors may affect the resulting production. It demands farmers to use the production factors to manage their farms effectively. One method that can be used to evaluate the optimal use of the production factors for cabbage farming is to measure its technical efficiency. It can be assumed that it is technically effective if there is a combination of input used and output generated along the production curve (Farrel, 1957). With technical efficiency, farmers can find out which factors in the cabbage production are not productive, so that farmers can control it and maximum productivity can be achieved. Technical efficiency shows the relationship between input and output. Technical efficiency tests the degree to which a farmer transforms inputs to outputs at a certain level of 
production, economic factors and other technologies (Nicholas, 1995).

The stochastic frontier production function is a method often used to estimate the level of technical efficiency. This model has been widely used to examine the technical efficiency of farming in Indonesia, including research on cabbage farming (Darmansyah, Sukiono, \& Sugiarti, 2013; Sari, Wicaksono \& Utami, 2013), potato farming (Rizkyah, Syafrial, \& Hanani, 2014; Shavgulidze, Bedoshvili, Aubacher, 2017; Maryanto, Sukiyono \& Priyono, 2018), corn farming (Aryanti, 2018), rice farming (Muhaimin, 2012), chili farming (Saptana, Arif, Heni \& Kuntjoro, 2010) and shallot farming (Eka, Idkan \& Siti, 2018).

The technical efficiency analysis used in most studies uses the Cobb-Douglas production function, with the advantages of being able to describe the state of the yield scale (return to scale) whether it is in an increasing, constant or decreasing position and is capable of describing the production elasticity of each input used and to describe the inputs efficiency used in the outputs production from the production system (Coelli, et.al 1998).

Apart from being determined by the combination of the use of production inputs, the level of farm efficiency is also influenced by the socio-economic characteristics of the farmers derived from the farmers themselves. Production factors that have been studied in a number of studies that include socio-economic variables are: Land size, land ownership status, farmer education and experience, access to finance, credit and information, and frequency of extension received by farmers (Ali \& Abbas, 2017; Supaporn, 2015; Aristar, 2018).

Farmers also faced some problems related to cabbage yields, such as low cabbage yields ranging from 24 to 28 tonnes per hectare whereas yields can be up to 40-50 tonnes per hectare because the Grand 11 seed variety is used. Based on this issue, this study formulates some research questions as follows: (1) To what extent the production factors of land area, seeds, labour, organic fertilizers, urea fertilizers, za fertilizers, npk fertilizers and pesticides have an effect on the cabbage production in Purwodadi district, (2) To what extent the degree of technical efficiency of cabbage farming can be increased in the Purwoadi district (3) Do the production factors such as soil, seeds, labor, organic fertilizer, urea fertilizer, za fertilizer, NPK fertilizer and pesticides affect the level of technical inefficiency of cabbage farming in the Purwoadi district and (4) How many profits of cabbage farming at the research site, Gerbo Village, Purwodadi District, Pasuruan Regency.

\section{Research Methodology}

The location was selected purposively on the basis that it was a vegetable production centre in Pasuruan Regency, in Gerbo Village, Purwodadi District. The respondent's selection, the cabbage farmers, were carried out by simple random sampling. The researcher used the Slovin formula as a sampling technique. The total number of respondents was 67 farmers. Data were collected once during the planting season, from August to November 2019.

The current study used Stochatic Frontier Analysis (SFA) approach. This approach is also used in many studies because it has many advantages. The benefit of using the Stochatic Frontier analysis approach, according to Coelli et al (1998), is that it can be used directly to evaluate hypotheses relevant to the production model. Stochatic Frontier is more applicable to crosssection data with an error term that has two components, namely random effects and technological inefficiency, in order to eliminate bias caused by random errors. The Stochatic Frontier can also determine the maximum potential that can be accomplished by farming with the input combination used. Thus, in order to achieve the objectives of this study, the SFA method is a choice for hypotheses testing, since SFA uses statistical techniques to estimate parameters. The Cobb-Douglas type of SFA is widely used in many empirical studies, particularly related to agricultural development. (Battese and Coelli, 1998).

Logically, the stochastic frontier production function for cabbage farming is assumed to have the form of a Cobb-Douglas equation model that is converted into a logarithmic form as follows:

$$
\begin{aligned}
\operatorname{Ln} \mathrm{Y}= & \beta_{0}+\beta_{1} \operatorname{Ln} x_{1}+\beta_{2} \operatorname{Ln} x_{2}+\beta_{3} \operatorname{Ln} x_{3}+\beta_{4} \operatorname{Ln} x_{4} \\
& +\beta_{5} \operatorname{Ln} x_{5}+\beta_{6} \operatorname{Ln} x_{6}+\beta_{7} \operatorname{Ln} x_{7}+\beta_{8} \operatorname{Ln} x_{8}+ \\
& \left(v_{1}-u_{1}\right)
\end{aligned}
$$

In which:

$\mathrm{Y}=$ cabbage production (tonnes $/$ ha), $\beta 0=$ Intercept constant, $\beta 1-\beta 8=$ estimator parameter coefficient, $\mathrm{X}_{1}=$ land area (hectares), $\mathrm{X}_{2}=$ labor (Hok), $X_{3}=$ seeds (seeds), $X_{4}=$ organic fertilizer $(\mathrm{kw}), \mathrm{X}_{5}=$ urea fertilizer $(\mathrm{kw}), \mathrm{X}_{6}=$ za fertilizer $(\mathrm{kw}), \mathrm{X}_{7}$ - npk fertilizer $(\mathrm{kw}), \mathrm{X}_{8}=$ pesticide (liter), 
$u_{1}=$ random variable, $v_{1}=$ technical inefficiency effect on the model.

The model is estimated using OLS and MLE methods. OLS (Ordinary Least Square) is an estimate of the $\beta \mathrm{j}$ parameter, which only has the feature of being able to see the average performance of farmers and not being able to see differences in management skills among farmers. The MLE (Maximum Likelihood Estimation) approach is used to estimate $\beta 0-\beta 8$ parameter and $u i$ and $v i$ variant.

Measuring the technical efficiency of cabbage farming is calculated using the equation formulated by Battese \& Coelli (1988) and Kumbhakar \& Lovell (2000) as follows:

$$
\mathrm{TE}=\frac{\mathrm{Y}}{\mathrm{Y}}, \exp \left(-u_{i}\right)
$$

In which:

$$
\begin{array}{ll}
\mathrm{TE} & =\text { Technical efficiency } \\
\mathrm{Y} & =\text { Actual production } \\
\mathrm{Y}^{\prime} & =\text { Potential production }
\end{array}
$$

$\operatorname{Exp}(-u i)=$ The expected mean value of the ui/technical inefficiency on the model

The value of TE ranges from 0 to 1 . The high value of ui implies the high inefficiency of the cabbage farming being handled, since there is a difference in output between the maximum yields of production, which are increasing. If the TE value is closed to 1 then the farming being carried out is more productive and vice versa, if it is closed to 0 implies that the farming is increasingly inefficient.

Meanwhile, the Tobit regression is used to evaluate factors contributing to the technical efficiency of cabbage farming. This model is used to examine the factors influencing the technical inefficiency of cabbage farming. This analysis is used because the output data used in this function is censored data, limited to 0 to 1 . The estimation model equations which affect the technical inefficiency that can be formulated are as follows:

$$
\begin{aligned}
\mathrm{TE}_{\mathrm{i}}= & \alpha_{0}+\alpha_{1} \mathrm{Z}_{1}+\alpha_{2} \mathrm{Z}_{2}+\alpha_{3} \mathrm{Z}_{3}+\alpha_{4} \mathrm{Z}_{4}+\alpha_{5} \mathrm{Z}_{5}+\alpha_{6} \mathrm{Z}_{6} \\
& +\mathrm{u}_{\mathrm{i}}
\end{aligned}
$$

In which:

$\mathrm{TEi}=$ technical inefficiency, $\mathrm{Z}_{1}-\mathrm{Z}_{6}=$ parameter whose value is estimated through the estimator model, $\alpha_{0}=$ intercept, $Z_{1}=$ age (years), $Z_{2}=$ number of family members (people), $Z_{3}=$ education (years), $\mathrm{Z}_{4}=$ number of extension frequency followed by (times), $Z_{5}=$ land ownership dummy $(1=$ own property, $0=$ rent $), Z_{6}$ $=$ credit access dummy (IDR) $(1=$ credit access, 0 $=$ no credit $), \mathrm{u}=$ standard error.

The parameters used are the Stata ver 11 programs. Likelihood ratio setest is used to test the estimate of parameter at the same time. The test of partial parameter uses the $\mathrm{Z}$ test. It is a test of the significant effect of independent input on the dependent input separately, namely by looking at the probability value by comparing the probability and the trust value $(\alpha)$. If the probability is less than the allowed trust (5-007) 0.1, the input will have a significant impact.

To determine the income level of cabbage farming in Gerbo Village, Purwodadi District, it can be seen from the disparity between income and costs incurred. The amount of total acceptance, cost and revenue may be formulated as follows:

$$
\begin{array}{ll}
\mathrm{TR} & =(\mathrm{Py}) \mathrm{x}(\mathrm{Y}) \\
\mathrm{TC} & =\mathrm{TFC}+\mathrm{TVC} \\
\pi_{\text {cash }} & =\mathrm{TR}_{\text {total }}-\mathrm{TC}_{\text {cash }} \\
\pi_{\text {cash }} & =\mathrm{TR}_{\text {cash }}-\left(\mathrm{TC}_{\text {cash }}+\mathrm{Bd}\right) \\
\text { Information: } & \\
\mathrm{TR} & =\text { Total cash revenues (IDR / season) } \\
\mathrm{TC} & =\text { Total cash costs (IDR season) } \\
\pi & =\text { Income (IDR / season) } \\
\mathrm{Py} & =\text { Price of output (IDR / season) } \\
\mathrm{Y} & =\text { Total output (R / season) } \\
\mathrm{TFC} & =\text { Total fixed costs (IDR / season) } \\
\mathrm{TVC} & =\text { Total variable costs (IDR / season) } \\
\mathrm{Bd} & =\text { Calculated cost (IDR / season) }
\end{array}
$$

\section{Findings and Discussion}

\subsection{Frontier Production Function}

This study investigated the analysis of the projected production function of cabbage farming by using the stochastic frontier production approach. This approach can be used to estimate the degree of technical efficiency and the factors affecting the technical efficiency of agriculture. Estimated parameters are used in the stochastic frontier production function to evaluate the factors affecting the production of cabbage. The results are shown in Table 1 below. 
Table 1. The Estimation Result of Stochastic Frontier Function Model on Cabbage Farming with MLE

\begin{tabular}{lllll}
\hline \multirow{2}{*}{ Variable } & \multirow{2}{*}{ Parameter } & \multicolumn{3}{c}{ Maximum Likelihood Estimation (MLE) } \\
\cline { 3 - 5 } & & Coeficient & Standart Error & t-count \\
\hline Intercept & $\beta^{0}$ & 1.6617 & 0.0765 & 21.7195 \\
Land area & $\beta^{1}$ & 0.0664 & 0.0161 & $* * 4.1197$ \\
Labor & $\beta^{2}$ & 2.4711 & 0.2300 & $* * * 10.7414$ \\
Seeds & $\beta^{3}$ & 0.2189 & 0.0185 & $* * * 11.8120$ \\
Organic Fertilizer & $\beta^{4}$ & 0.5429 & 0.0934 & $* * * 5.8067$ \\
Urea Fertilizer & $\beta^{5}$ & 0.0670 & 0.0245 & $* * * 2.7291$ \\
Za Fertilizer & $\beta^{6}$ & 0.0242 & 0.0122 & $* 1.9784$ \\
Npk Fertilizer & $\beta^{7}$ & -0.0457 & 0.0100 & $* *-4.5587$ \\
Pesticide & $\beta^{8}$ & 0.0179 & 0.0184 & 0.9743 \\
Sigma Squared & $\delta^{2}$ & 0.0229 & 0.0038 & $* * * 6.0334$ \\
Gamma & $\Upsilon$ & 0.9990 & 0.0005 & $* * * 19.9724$ \\
\hline
\end{tabular}

Log Likelhood Fuctiont $=78.6477$

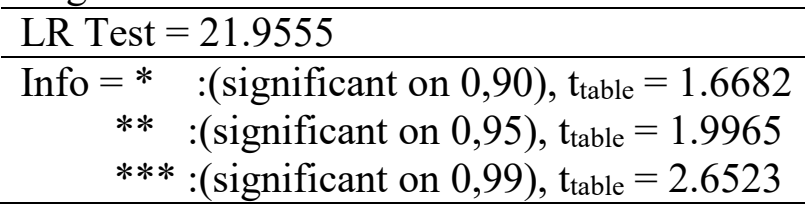

The projected stochastic frontier production function of cabbage farming is shown in Table 1 above. It can be seen that land area, labor, seeds, organic fertilizers, urea fertilizers and NPK fertilizers at a $1 \%$ significance level, za fertilizers at a $10 \%$ significance level are the seven factors influencing the output of cabbage in the Gerbo Village. While the pesticide variable did not significantly affect the yield of the cabbage farm at $1 \%, 5 \%$ and $10 \%$ levels of significance. The descriptions are as follows:

Land area, $\mathrm{t}$ test results with a significance level of $1 \%$, the $t_{\text {count }}$ value of 4.1197 is greater than the $t$ table value of 2.6523 . The $t_{\text {count }}$ value that is greater than the $t_{\text {table }}$ value indicates that the land area production factor has a positive and important impact on the cabbage farm production. The land area production factor has a positive coefficient value of 0.0664 , which indicates that an increase in land area by $1 \%$ would increase production by 0.0664 per cent with other production factors considered constant (cateris paribus). Land has a positive effect since the land at the research site is fertile and ideal for horticultural cultivation, in particular vegetables. The area of ownership or control of land is linked to the technical efficiency of cabbage farming. The use of inputs would be more effective if the area of land managed is larger. (Soekartawai, 1990). This finding is supported by the results of research by: Muhaimin (2012) on organic rice farming; Eka, Idkan and Siti (2018) on shallot farming; as well as
Maryanto, Sukiyono, and Priyono (2018) on potato farming, which show that land area variables have a very significant and positive impact on the amount of production.

Labor, the results of the t-test with a significance level of $1 \%$, the $t_{\text {count }}$ value of 10,7414 is greater than the $t_{\text {table }}$ value of 2,6523 . The $t_{\text {count }}$ value, which is greater than the table value, indicates that the factor of production using the quantity of labour has a positive and important impact on the production of the cabbage farm. Labor production factor has a positive coefficient value of 2.4711, which indicates that the addition of labor production factors by $1 \%$ would increase production by $2.4711 \%$ with other production factors considered constant (cateris paribus). The addition of labour would increase the yield of cabbage with the contribution of maintenance activities such as irrigating, spraying and continuous weeding. As most of the cabbage farmers have argued, intensive care is needed in the process of cabbage farming, especially in the process of treating weeds and pests, so a lot of labor is needed for this cabbage farming process. These findings are same as results of research by: Muhaimin (2012) on organic rice farming; Darmansyah (2013) on cabbage farming; Riskiyah, Syafrial, Hanani (2014) on potato farming; and Ali Chandio, Abbas et al (2017) on rice farming. They reported that labor variable had a major and positive impact on the amount of production. 
Seeds, the t-test results with a significance level of $1 \%$, the $t_{\text {count }}$ value of 11.8120 is greater than the $t_{\text {table }}$ value of 2.6523 . The $t_{\text {count }}$ value, which is greater than the $t_{\text {table }}$ value, indicates that the seed used factor has a positive and important impact on the production of cabbage. The seed production factor has a positive coefficient value of 0.2189 , which indicates that the addition of $1 \%$ of the seed production factor would increase production by $0.2189 \%$ with other production factors considered constant (cateris paribus). Increasing the number of seeds is necessary because it will produce large amounts of cabbage, in other words, production is very sensitive to the use of the number of seeds so that the increased use of seeds will increase the production of cabbage. Respondents mostly used about 24,000 cabbage seeds, some of them used 28,000 cabbage seeds with an average yield of 28 tons/hectare. This finding may be linked to the results of research that the addition of cabbage seeds still has the potential to increase production so it will achieve a production rate of 40-60 tons/hectare. It is in line with research by Darmansyah (2013) and Sari, Wicaksono, Utami (2013) on cabbage farming that the variable seed/seed has a significant and positive impact on the amount of production.

Organic fertilizers, the results of the t-test with a significance level of $1 \%$, the $t_{\text {count }}$ value of 5,8067 is greater than the $t_{\text {table }}$ value of 2,6523 . The $t_{\text {count }}$ value, which is greater than the $t_{\text {table }}$ value, shows that the manure production factor has a positive and important impact on the cabbage production. The effect of using the amount of organic fertilizer on the cabbage production is shown by a coefficient of 0.5429 , which indicates that the addition of $1 \%$ of the organic fertilizer production factor would increase production by $0.5429 \%$ with other production factors considered constant (cateris paribus). Positive production facilities show that the use of organic fertilizers in reasonable areas can also increase the use of organic fertilizers, which is useful for increasing the cabbage production.

In the cultivation technique of cabbage, fertilizers are used in the form of manure and artificial, for cow manure 30 tons/hectare, for sheep manure 20 tons/hectare or for rice straw compost up to 18 tons/hectare. (Indonesian Agricultural Research and Development Institute, 2019). In practice, however, most cabbage farmers do not pay attention to instructions on how to use manure. The lack of use of manure is also due to the fact that they believe that the land used for cultivation is fertile, assuming that in land irrigation the water used is mixed with cow dung. The use of organic fertilizers needs to be increased because several research findings indicate that variable organic fertilizer has a significant and positive effect on the amount of production, for example Muhaimin (2013)'s research on organic rice farming; Darmansyah (2013)'s research on cabbage farming; Rizky, Syafrial, Hanani (2014)'s research on potato farming.

Urea fertilizer, t-test results with a significance level of $1 \%$, the $t_{\text {count }}$ value of 2,7291 is greater than the $t_{\text {table }}$ value of 2,6523 . The $t_{\text {count }}$ value, which is greater than the $t_{\text {table }}$ value, indicates that the urea fertilizer production factor has a positive and important impact on the cabbage production. The effect of using the amount of urea fertilizer on the cabbage production is shown by a coefficient of 0.0670 , which indicates that the addition of $1 \%$ of the urea fertilizer production factor would increase production by $0.0670 \%$ with other production factors considered constant (cateris paribus). The average urea fertilizer used by the respondent farmers was $404 \mathrm{~kg} /$ hectare, which, according to the recommendation of the Agricultural Extension Agency of $100 \mathrm{~kg} /$ hectare (Agricultural Research and Development Agency, 2019). It indicates that excessive use of urea is due to the lack of attention at the time of extension, and the majority of the respondent farmers still use the inherited system or expereince from their families. The use of urea fertilizer should be observed because several research findings indicate that the organic fertilizer variable has a significant and positive effect on the amount of production. It is in line with Darmansyah (2013)'s research which reports that the urea fertilizer variable has a significant and positive effect on the cabbage production.

$\mathrm{Za}$ fertilizer, t-test results with a significance level of $10 \%$, the $t_{\text {count }}$ value of 1,9784 is greater than the $t_{\text {table }}$ value of 1,6682 . The $t_{\text {count }}$ value greater than the $t_{\text {table }}$ value indicates that the za fertilizer production factor has a positive and important impact on the cabbage production. The effect of the use of za fertilizer dosage on the cabbage production is shown by the coefficient of 0.0242 , which shows that the addition of za fertilizer production factor by $1 \%$ would increase production by $0.0242 \%$ with other production factors considered constant (cateris paribus). 
Fertilizer is an essential component to maximum production. Applying the right dosage of fertilizer will increase yields. The recommendation for use of ZA fertilizer is $250 \mathrm{~kg}$ per hectare (Agricultural Research and Development Agency, 2019). In practice, the average amount of za fertilizer used by the respondent farmers was $309 \mathrm{~kg} /$ hectare. It shows that the excessive use of za fertilizer by farmers is due to a lack of attention at the time of extension, and most of the respondent farmers still use the inherited system or experience from their families. Therefore, the use of za fertilizer needs to be observed because some research results indicate that the za fertilizer variable has a significant and positive effect on the amount of production, in line with research by Darmansyah (2013) indicated that the urea fertilizer variable has a significant and positive effect on the cabbage production.

Npk fertilizer, t-test results with a significance level of $1 \%$, the $t_{\text {count }}$ value of $-4,5587$ is greater than the $t_{\text {table }}$ value of 2,6523 . The $t_{\text {count }}$ value which is greater than the $t_{\text {table }}$ value implies that the NPK fertilizer production factor has a negative impact on the cabbage production. The effect of the amount of Npk fertilizer used on the cabbage production is shown by a coefficient of 0.0457 , which indicates that the addition of the Npk fertilizer production factor by $1 \%$ reduces production by $-0.0457 \%$ with other production factors considered constant (cateris paribus). The average NPK fertilizer used by the respondent farmers was $124 \mathrm{~kg} /$ hectare, in which the agricultural extension agency recommends 200 $\mathrm{kg} /$ hectare (Balitbang Pertanian, 2019). This signifies that the use of NPK fertilizer is not feasible due to the expensive price, and the difficulties in obtaining the supply of fertilizer. In addition, most farmers involved either use the inherited method or experience from their families. It is therefore necessary to pay attention to the use of NPK fertilizer because some research results indicate that the variable NPK fertilizer has a significant effect on the amount of production, in line with research by Darmansyah (Rohmad Budiono, 2019) stated that NPK fertilizer has a significant effect on the growth and yield of cabbage plants.

\subsection{Technical Efficiency of Cabbage Farming}

The level of technical efficiency achieved by each cabbage farmer shall be categorized from the lowest level of efficiency to the highest level of efficiency. Closely related to Darmasyah (2013) cabbage farming study, the lowest efficiency level is 0.78439 , the average efficiency level is 0.91195 and the maximum efficiency level is 0.99789 .

In this study, the efficiency achieved by the respondent farmers, starting from the minimum, average, and maximum level of technical efficiency, is provided in Table 2.

Table 2. Distribution of Respondent Farmers Based on the Level of Technical Efficiency of Cabbage Farming

\begin{tabular}{llcc}
\hline No & $\begin{array}{l}\text { Level of } \\
\text { Technical } \\
\text { Efficieny }\end{array}$ & $\begin{array}{c}\text { Total } \\
\text { (Person) }\end{array}$ & $\begin{array}{c}\text { Percentage } \\
\mathbf{( \% )}\end{array}$ \\
\hline 1. & TE $\leq 0.5$ & 0 & 0.00 \\
2. & $0.5 \leq \mathrm{TE} \leq 0.6$ & 1 & 1.49 \\
3. & $0.6 \leq \mathrm{TE} \leq 0.7$ & 0 & 0.00 \\
4. & $0.7 \leq \mathrm{TE} \leq 0.8$ & 3 & 4.47 \\
5. & $0.8 \leq \mathrm{TE} \leq 0.9$ & 26 & 38.80 \\
$6 . \quad 0.9 \leq \mathrm{TE} \leq 1.0$ & 37 & 55.22 \\
\hline Total & 67 & 100.00 \\
\hline Average TE & \multicolumn{2}{c}{0.9037} \\
Minimum TE & \multicolumn{2}{c}{0.5968} \\
Maximum TE & \multicolumn{2}{c}{0.9994} \\
\hline
\end{tabular}

The results of the technical efficiency achieved for each respondent farmer have different values. The maximum efficiency value held by farmers is 0.9994 and the minimum efficiency value for farmers is 0.5968 , while the average technical efficiency in the study field is 0.9037 . This mean value implies that the level of technical efficiency at research site is rated as high efficiency, for instance 66 farmer respondents or $98,51 \%$ have an efficiency value $(0.70 \leq \mathrm{TE} \leq$ $1.00)$ since the value is closed to the expected level of efficiency, which is 1 . It also demonstrates that the ability of farmers to use minimum inputs to achieve a certain level of outputs still needs to be enhanced. This average efficiency level shows that the use of inputs from production can still be saved, with farmers saving up to $9.63 \%$ of inputs. The efficacy value of each respondent farmer at the study location is shown in Figure 1. 
Technical Efficiency of Cabbage Farming

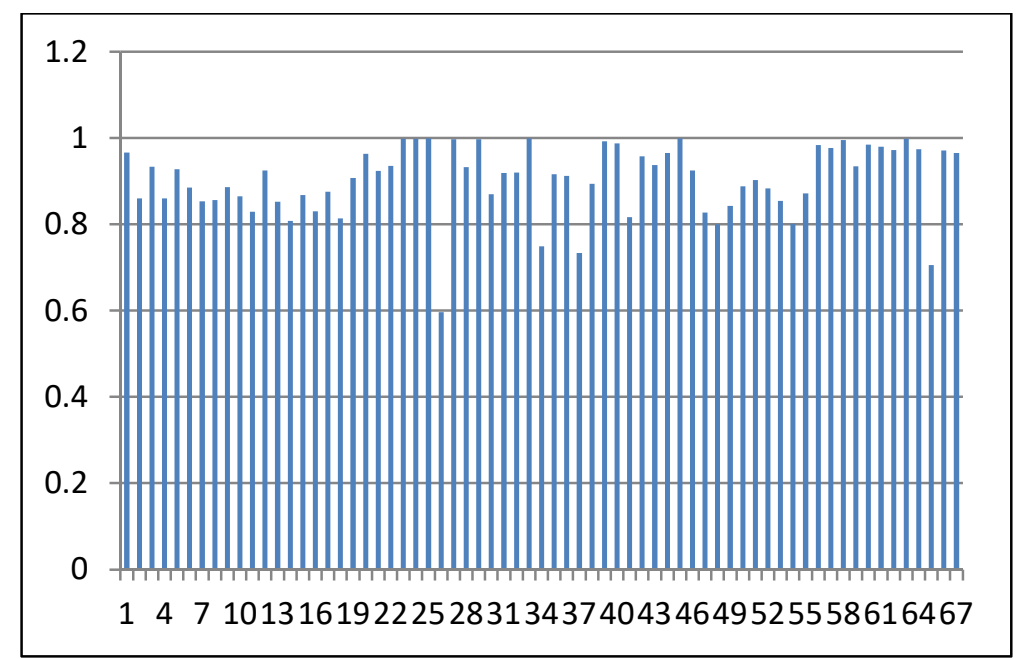

Figure 1. Distribution of Technical Efficiency for Each Cabbage Respondent Farmers

Table 2 revealed that the maximum efficiency value in the $0.9 \leq \mathrm{TE} \leq 1.0$ category is 37 farmers or $55.22 \%$ of the total respondent farmers. It means that most farmers have a value between 0.9026 and 0.9994 but have also achieved a technical efficiency level that is higher than the average. Whereas farmers with an efficiency level below the average are 30 farmers or 44.78 per cent of the total respondent farmers, so that they can be the main target to engage in counseling in order to improve farm management and those who are not productive in agriculture can work more effectively, and open opportunities for farmers to achieve maximum production results.

While it is claimed to be effective with an average technical efficiency of 0.9037 , it is lower than the efficiency value at national level (provincial level cabbage producers). The productivity of cabbage in Indonesia is an average of 21,30 tons per hectare in 2018 . The productivity value of cabbage at the research site, with an average of 28 tons/hectare, is now above the national average productivity, but still below the productivity level between the provinces: West Sumatra, Bengkulu, Bali and East Kalimantan, each of which has 31 productivity tons, 13 tons/hectare, 35.24 tons/hectare, 30.81 tons/hectare, 40.00 tons/hectare. Research carried out in the province of Bengkulu, the average value of the technological efficiency of cabbage farming was 91,195 . The efficiency value at the research site is lower than the results of the Bengkulu Province study. Therefore, the respondent farmers in Gerbo Village, Purwodadi District, Pasuruan Regency still have a chance to increase the value of technical efficiency.

\subsection{Factors of Cabbage Farming Technical Inefficiency}

Tobit regression analysis was used to assess the factors affecting the technical inefficiency of cabbage farming in Gerbo Village, Purwodadi District, Pasuruan Regency. Table 15 shows that there are three variables that have a major impact on the technological inefficiency of cabbage farming.

Table 3. Results of Tobit Regression Analysis About Factors Affecting Technical Inefficiency of Cabbage Farming in Gerbo Village in 2019

\begin{tabular}{lllr}
\hline Variable & Coefficient & z-Statistic & Prob. \\
\hline C & .162339 & 1.89 & 0.058 \\
Age & -.0021763 & -2.23 & $* 0.026$ \\
JAK & -.0034073 & -0.34 & 0.733 \\
Education & -.0055178 & -1.91 & $* 0.056$ \\
$\begin{array}{l}\text { Frequency of } \\
\text { Extension }\end{array}$ & -.0002846 & -0.15 & 0.882 \\
$\begin{array}{l}\text { Land } \\
\text { Ownership }\end{array}$ & .0177811 & 0.58 & 0.560 \\
$\begin{array}{l}\text { Dummy } \\
\text { Credit Access }\end{array}$ & -.0807815 & 2.07 & $* 0.038$ \\
Dummy & & & \\
\hline
\end{tabular}

The findings show that the age variable has a significant and negative impact at $97.4 \%$, the education variable has a significant and negative effect at $94.4 \%$ and the credit access dummy has a significant and negative effect on the real level of $96.2 \%$. While the JAK variable, the frequency of extension and the land ownership dummy have no effect on the technical inefficiency of cabbage 
farming in Gerbo Village, Purtwodadi District. For a detailed information, see the explanation below:

The age of the respondent farmer negatively affects the trust level of $97.4 \%$ on the effects of technical inefficiency in cabbage farming. The coefficient of 0.0021763 means that with one-year old adds, the degree of technological inefficiency is reduced by 0.0021 . It has a negative or inversely proportionate impact on technical inefficiency. The older the farmer, the lower the inefficiency. Respondent farmers in the cabbage farm at research area, if taken from the individual characteristics, the average age of the farmer as the head of the family is 54.19 and the percentage of all respondent farmers is 71.63 per cent in a productive age (46-65 years). It shows that, as the age of the farmer grows, the farmer will have more knowledge in farming and will be more mature in taking a policy to determine farming decisions. Thus, the use of production factors can be more effective and can ultimately increase the production of cabbage. It is similar to research conducted by Rizkiyah, Syafrial, Hanani (2014), and Aristar Manurung, Hendrik (2018) that the age variable affects technical inefficiency.

Education, as seen from the variable level of education, has a negative impact on the technical inefficiency of cabbage farming at $94,4 \%$ of the trust level. The coefficient of 0.005178 implies that with a one-year improvement in education, the degree of technological inefficiency would decrease by 0.0055 . It has negative or inversely proportional impact on technical inefficiency. The higher the education of farmers, the lower the inefficiency and shows that the longer education takes, the more effective it is. In line with research conducted by (Fauzi, 2018) that the coefficient of educational variables is negative. The higher education farmers had, the more farmers obtain knowledge and technology for agricultural cultivation. It means that education is a critical variable that can improve productivity. The farmer's formal education variable is used as a management input, where the level of farmer education would have an effect on decisionmaking in farming. This decision involves crucial decisions on the optimal use of inputs. According to Kedebe (2001), education improves farmers' ability to seek, obtain and interpret useful information on inputs from production. It suggests that a high level of education would also have an effect on farmers' willingness and ability to obtain knowledge on the use of production factors.

Current conditions show that the characteristics of the respondent farmers from the average level of education are low (4.89). It shows that they have not completed elementary school and also that $57,77 \%$ of all responsive farmers are at the level of education (SD). This situation shows that the education of farmers is relatively poor, so that it becomes a problem of productivity. It can also be the reason for government policy to improve farmer education and management.

Credit Access Dummy, the variable access to credit has negative effect on the trust level of $96.2 \%$. The coefficient 0,0807815 indicates that the degree of technical inefficiency in cabbage farming will be reduced by 0,0828 , a negative effect or inversely proportional to technical inefficiency, if the farmers have credit access for cabbage farming. The more farmers participate in credit access, the lower the level of inefficiency. It shows that credit access can help farmers to develop their farming. It is in line with research by Ali Chandio et al (2017) on rice farming in Sindh Pakistan. They stated that credit access is very influential and becomes a dominant factor in increasing rice production and technical efficiency of farmers. In other words, credit access can reduce inefficiency in the farming.

Access to credit plays an important role in making farming more profitable and effective. Facts showed that many farmers borrow at the beginning of planting and return it after harvesting. Many respondent farmers have some opinions on the usefulness of credit facilities, as the cost of capital for large-scale cabbage farming is approximately Rp. 30,000,000. This expense is what possible to borrow money. In real condition, there are limitations to the borrowing process in Gapoktan which is about Rp. 1,000,000 to Rp. $2,000,000$. As a result, most borrowers are not from financial institutions, but from relatives and neighbors. In this situation, there is a clear need for government support to allow farmers have access to credit. Research conducted by Fadwiwati, Hartoyo, Kuncoro, Rusastra (2013) indicated that variable credit access had negative impact on corn farming.

\subsection{The Analysis of Cabbage Farming Income}

The income of farmers is derived from the difference between the income and the costs that have been charged. The average revenue from 67 respondent farmers was per hectare in one season. 
As seen from the fluctuating sale price ranged from Rp. 1500 to Rp. 2500, then the selling price decided by 67 farmers was Rp. 2,200. Out of the total production and consumption of the respondent farmers, it is known that there are $28,000 \mathrm{Kg}$ and $101 \mathrm{Kg}$ respectively, so that cash revenue (cabbage vegetable production) and noncash revenue (consumption) can be measured at $61,600,000$ and 222,200 respectively. The total revenues were Rp. $61,600,000$. In the case of cabbage farming costs incurred by farmers, the cash costs amounted to Rp. $26,302,400$ or $85,46 \%$ of the total cost, while the non-cash costs or calculated costs were Rp. $4,472,500$ or $14,53 \%$ of the total cost. The average revenue of one cabbage farm per planting season per hectare is shown in Table 4.

Table 4 shows that the average cash revenues of the respondent farmers were Rp.61,600,000 and the cash revenues were Rp.222,200 then the total revenue was Rp61,822,200 The income of the respondent farmers is currently very high due to the high selling price. Based on the experience of respondent farmers in selling prices, it reveals that the lowest price was Rp. 500, the average price was Rp. 2,000 to Rp. 3,000, and the highest price ever achieved was Rp. 10,000/kg in 2012.

Table 4. The average revenue of one planting season per hectare of cabbage farming in Gerbo Village in 2019

\begin{tabular}{lcrr}
\hline Revenue & $\begin{array}{c}\text { Total } \\
(\mathbf{K g})\end{array}$ & $\begin{array}{c}\text { Price } \\
(\mathbf{R p} / \mathbf{K g})\end{array}$ & $\begin{array}{c}\text { Value } \\
(\mathbf{R p})\end{array}$ \\
\hline Cabbage & 28.000 & 2.200 & 61.600 .00 \\
& & & 01.600 .000 \\
\hline $\begin{array}{l}\text { Cash } \\
\text { revenue }\end{array}$ & & & \\
\hline $\begin{array}{l}\text { Consumpti } \\
\text { on }\end{array}$ & 101 & 2200 & 222.200 \\
\hline $\begin{array}{l}\text { Non-cash } \\
\text { revenue }\end{array}$ & & & 222.200 \\
\hline $\begin{array}{l}\text { Total } \\
\text { revenue }\end{array}$ & & & 61.822 .20 \\
\hline
\end{tabular}

The current cabbage price sold by respondent farmer is Rp. 1,500 to Rp. 2,500. This price is paid by the traders. Details of cabbage farming costs in one planting season can be seen in table 5 .

Tabel 5. Average Cost of Cabbage Farming for One Planting Season Per Hectare of Respondent Farmers in Gerbo Village

\begin{tabular}{lrrr}
\hline Information & Total & Price Unit (Rp) & \multicolumn{1}{c}{$\begin{array}{c}\text { Value } \\
\text { (Rp) }\end{array}$} \\
\hline Cash Costs & & & \\
\hline Seedling (seed) & 23550 & 100 & 2.350 .500 \\
TKLK (hok) & 313.08 & 35.000 & 10.957 .800 \\
Organic Fertilizer (kw) & 9.11 & 80.000 & 728.800 \\
Urea Fertilizer (kw) & 8.04 & 180.000 & 1.447 .200 \\
Za Fertilizer (kw) & 3.09 & 150.000 & 463.500 \\
Npk Fertilizer (kw) & 4.24 & 1.080 .000 & 4.579 .200 \\
Pesticide (liter) & 5.93 & 130.000 & 770.900 \\
Land Rent (musism) & 1,00 & 5.000 .000 & 5.000 .000 \\
\hline Total Cash Costs & & & $\mathbf{2 6 . 2 9 7 . 9 0 0}$ \\
\hline Calculated Costs & 112 & 35.000 & \\
\hline TKDK & 1,00 & 552.500 & 3.920 .000 \\
Tools Reduction & & & $\mathbf{4 . 4 7 2 . 5 0 0}$ \\
\hline Total Calculated Costs & & & $\mathbf{3 0 . 7 7 0 . 4 0 0}$ \\
\hline Total Costs & & &
\end{tabular}

At harvest time, the respondent farmers mostly sell them using a slash method, that is, the plants are sold to the trader when the plants are ready to be harvested. Respondent farmers will obtain the price decided by both parties, and the harvesting is the responsibility of traders. Farmers prefer to release them to middlemen or collectors, because they make harvesting easier and there are no labor costs involved in the harvesting process. There are a limited number of farmers selling directly to the market due to low yields or a planted area of less than 0.25 hectares. 
The cost of cabbage farming consists of cash and non-cash costs (calculated costs). Each value was Rp. 26,302,400 and Rp. 4,472,500. Cash costs are higher than non-cash costs, with a proportion of overall costs of $85.46 \%$ for cash costs and $14.53 \%$ for non-cash expenditures, respectively. The high percentage of cash costs resulting from the use of variables that are family labor (35.60\%), the use of npk fertilizer (14.87\%) and the value of land rent (16.24\%). The amount of costs incurred for outside family labor because for cabbage farming, care must be intensive, mostly in the treatment and control of pests. For pest control, spraying is mostly carried out using outside family labor, which can be sprayed every 3-7 days. In the farming process, this intensive maintenance uses a lot of labor to succeed in farming cabbage, hence good results and a high selling price are required. If the revenue is based on the cash cost and total cost, the cash cost is IDR $35,524,300$ and the total cost is IDR $31,051,800$.

\section{Conclusion}

The results of the stochastic frontier production function of the cabbage farms showed that almost all of the production factors used in the cabbage farming at research site had a significant effect on cabbage production. More effort is therefore required to increase the cabbage yields, because cabbage seeds are the most essential and most responsive factor in the cabbage production. It also cannot be separated from the proper use of production factors combination. The technical efficiency of cabbage farming achieved by farmers varies, with a minimum efficiency of 0.5968 and a maximum of 0.9994 , with an average value of 0.903 , shows that cabbage farming at the research site has achieved a good level of efficiency, with more than $50 \%$ of the technical efficiency above the average of $90.3 \%$. The average results of the technical efficiency of cabbage farming indicate that the performance of cabbage farming in the research area can be further increased. Production factors that affect technical inefficiency in cabbage farming includes the rising of farmers age, the increasing of farmers education level, and the use of credit access which has a major impact on the achievement of technical efficiency. Ease of access to financial institutions is very critical in making it easier for farmers to optimize cabbage farming, to obtain quality seeds and other inputs of production that are on time, quantity and price.
The frequency of extension and land ownership dummy does not have a major impact on the technical inefficiency of cabbage farming in Gerbo Village, Purwodadi District, Pasuruan Regency. Therefore, in order to increase the production of cabbage, it is still important to increase the involvement of extension workers in providing continuous extension in order to provide knowledge and understanding of technology and correct cultivation techniques for cabbage, as well as to increase the experience of farmers to engage in the counseling and training of cabbage cultivation techniques, both in nursery techniques, usage of superior varieties, and other cultivation techniques.

\section{References}

Ali Chandio, Abbas et al (2017) "The Nexus of Agricultural Credit, Farm Size and Technical Efficiency in Sindh, Pakistan: A Stochastic Production Frontier Approach". Journal of the Saudi Society of Agricultural Sciences.

Aristar Manurung, Asmara \& Marthen (2018). Analisis Efisiensi Teknis Usahatani Jagung Di Desa Maidu Kecamatan Montong Kabupaten Tuban: Menggunakan Pendekatan Stochastik Frontier Analysisi (SFA). JEPA Vol 2 No 4.

Coelli, T.J., D.S.P. Rao., C.J. Donnel and G.E Battese. 1998. An Introduction to Effyciency and Productivity Analysis Second Edition. Kluwer Academic Publisher. London

Darmansyah. 2013. Analisis Efisiensi Teknis dan Faktor yang Mempengaruhi Efisiensi pada Usahatani Kubis di Desa Talang BlitarKecamatan Sidang Dataran Kabupaten Lejang Lebong. AGRISEP Vol 12 No 2

Eka, Idkan \& Siti. 2018. Analisis Efisiensi Produksi Bawang Merah di Kabupaten Pati dengan Fungsi Produksi Frontier Stokastik Cobb-Douglas. Jurnal Agro Ekonomi, Vol 3 No 1

Farrel, M. J. 1957. The Measurement of Productive Efficiency.Journal of Royal Statistic Society, Series A, 253-281

Maryanto, Sukiyono, dan Priyono (2018) tentang Analisis Efisiensi Teknis dan Faktor Penentunya pada Usahatani Kentang 
(Solanumtuberosum L.) di Kota Pagar Alam, Provinsi Sumatera Selatan.AGRARIS Vol 4 No 1.

Muhaimin, Abdul Wahib. 2012. Analisis Efisiensi Teknis Faktor Produksi Padi (Oryza Sativa) Organik Di Desa Sumber Pasir, Kecamatan Pakis, Kabupaten Malang. AGRISE. Vol 12 No 3.

Rizkyah Noor, Syafrial, Nuhfi Hanani. 2014. Faktor- Faktot yang Mempengaruhi Efisiensi Teknis Usahatani Kentang (Solanum Tuberosum L.) dengan pendekatan Stochastic Production Frontier. (Kasus Desa Sumber Brantas Kecamatan Bumiaji Kota Batu). HABITAT.Vol xxv. No.1

Rohmad, Budiono (2019). Pengaruh Pupuk pada Pertumbuhn Tanaman Kubis. Diakses digital library. Ump. ac. id pada tanggal 12 mei 2019

Sari, Wicaksosno, Utami (2013). Analisis efisiensi Usahatani Kubis (Brassica Oleracea) Di Desa Sukomakmur Kecamatan Kajoran Kabupaten Magelang. Jurnal Surya Agritama. Vol 2 No 1

Supaporn .2015. tentang. Determinants of technical efficiency of sugarcane production among small holder farmers in Lao PDR dengan model fungsi fronter Cobb-Douglass. 